\title{
PCL/Andiroba Oil (Carapa guianensis Aubl.) Hybrid Film for Wound Healing Applications
}

\author{
Debora F. Silva ${ }^{1}{ }^{\mathbb{D}}$, Klinsmann T. Lima ${ }^{2}$, Gilmara N. T. Bastos ${ }^{2}$, Johnatt Allan R. Oliveira ${ }^{3}$, \\ Luís Adriano S. do Nascimento ${ }^{1} \mathbb{D}$, Carlos Emmerson F. Costa ${ }^{1}$, Geraldo N. R. Filho ${ }^{1} \mathbb{D}$, Viktor O. C. Concha ${ }^{4} \mathbb{D}$ \\ and Marcele F. Passos $1, *$ (D) \\ 1 Laboratory of Oils of the Amazon, Federal University of Pará, Belém 66075-750, PA, Brazil; \\ dfsdeborafreitas@gmail.com (D.F.S.); adrlui1@yahoo.com.br (L.A.S.d.N.); emmerson@ufpa.br (C.E.F.C.); \\ geraldonrf@gmail.com (G.N.R.F.) \\ 2 Laboratory of Neuroinflammation, Federal University of Pará, Belém 66075-110, PA, Brazil; \\ klinsmanntl@gmail.com (K.T.L.); bastosgnt@gmail.com (G.N.T.B.) \\ 3 Department of Nutrition, Federal University of Pará, Belém 66073-040, PA, Brazil; johnattrocha@yahoo.com.br \\ 4 Department of Chemical Engineering, Federal University of São Paulo, Diadema 09913-030, SP, Brazil; \\ viktor.cardenas.c@gmail.com \\ * Correspondence: cellepassos@ufpa.br; Tel.: +55-91-98964-9174
}

check for

updates

Citation: Silva, D.F.; Lima, K.T.; Bastos, G.N.T.; Oliveira, J.A.R.; do Nascimento, L.A.S.; Costa, C.E.F.; Filho, G.N.R.; Concha, V.O.C.; Passos, M.F. PCL/Andiroba Oil (Carapa guianensis Aubl.) Hybrid Film for Wound Healing Applications. Polymers 2021, 13, 1591. https://doi. org/10.3390/polym13101591

Academic Editors: Cédric Delattre and Ahmed M. Eissa

Received: 4 February 2021

Accepted: 13 March 2021

Published: 14 May 2021

Publisher's Note: MDPI stays neutral with regard to jurisdictional claims in published maps and institutional affiliations.

Copyright: (C) 2021 by the authors Licensee MDPI, Basel, Switzerland. This article is an open access article distributed under the terms and conditions of the Creative Commons Attribution (CC BY) license (https:// creativecommons.org/licenses/by/ $4.0 /)$

Abstract: Developing a biomimetic material to wound care is an emerging need for the healing process. Poly ( $\varepsilon$-caprolactone) (PCL) is a polymer with the necessary dressing's requirements often used in medicine. Their surface, physic-chemical and biological properties can be modified by adding bioactive compounds, such as andiroba seed oil (Carapa guianensis). This Amazonian natural plant has medicinal and pharmacological properties. For this purpose, PCL polymeric films incorporated with andiroba oil were investigated. The synthesis of hybrids materials was carried out in the solvent casting method. Thermal properties were evaluated using thermogravimetric analysis (TGA/DTGA) and differential scanning calorimetry (DSC). The solvent type on the surface and hydrophilicity of samples was studied using a scanning electron microscope (SEM). Additionally, contact angle measurements, functional groups analysis, fluid absorption capacity, and cell viability were performed. The results demonstrated the influences of andiroba oil under the morphology and thermal properties of the polymeric matrix; the hydrophilicity of the hybrid film obtained by acetic acid was reduced by $13 \%$; the porosity decreased as the concentration of oil increased, but its higher thermal stability. The L929 cell line's proliferation was observed in all materials, and it presented nontoxic nature. It was demonstrated the ability of PCL hybrid film as a matrix for cell growth. Then, the materials were proved potential candidates for biomedical applications.

Keywords: polycaprolactone; wound healing; andiroba oil; polymer; cell viability

\section{Introduction}

Researchers have aroused interest in using biomimetic dressings, with bioactive properties and as carriers of medicines, mainly for exudative wounds or resulting from prolonged pressure on the skin [1,2]. These sterile therapeutics covers may interact and imitate harmful tissue, reducing the time for treating the lesion, with cell regeneration and proliferation in the affected region; they have adequate porosity and fluid absorption capacity. Dressings must also avoid complications for the patient, differentiating themselves in physical and chemical terms to meet different biological and mechanical needs. Thus, they need to be easy to apply and remove; they must have nontoxic, nonallergenic, and biocompatible properties.

Hydrogels and silicones are commonly used as smart dressings for exudative wounds due to the high potential for swelling $[3,4]$. However, they have been causing inflammation and harmful monomers' release during treatment $[5,6]$. Thus, the search for bioactive 
materials with good biological properties and low-cost becomes essential. Moreover, technological advances in wound dressings are no longer restricted to producing materials with static purposes of mechanical protection and gas exchange through the membrane. The transport of therapeutic compounds such as hormones, anticancer agents, drugs, and other assets has enabled patients to be more independent and practical [7-10].

Poly ( $\varepsilon$-caprolactone) (PCL) has been applied in conjunction with other additives for use in biomedical applications. It is an acyclic polyester with excellent elastic, biodegradable, and bioabsorbable properties [11]. The Food and Drug Administration has approved PCL to use in drug delivery devices and various structures as nanospheres, nanofibers, foams, meshes, membranes, and scaffolds $[12,13]$. Furthermore, as a temporary substitute (scaffold) of the cell-matrix, the PCL allows cell adhesion and stimulates new ones' growth [14]. Muwaffak et al. [15] produced polycaprolactone filaments interspersed with antimicrobial metals using a hot-melt extruder and 3D printing techniques, obtaining potent antibacterial dressings. Poly ( $\varepsilon$-caprolactone) nanofibers coated with chitosan and gamma oryzanol also showed results for wound healing in mice [16]. On the other hand, incorporating vegetable oils in hybrid nanocarriers has decreased cytotoxicological effects and increased the dressing's antimicrobial properties [17]. Cardoso et al. [18] evaluated the effect on molar mass distribution of jojoba and andiroba oil encapsulation by miniemulsion polymerization. Uscátegui et al. [19] studied the cytotoxicity and antibacterial activity of polyurethanes based on modified castor oil and polycaprolactone. However, few studies on the intercalation of vegetable oils under alpha-hydroxy ester polymeric matrices and their potential for wound healing have been discussed in the literature via solvent casting technique. The possibility of adding bioactive natural compounds to PCL molecular chains represents a springboard to produce new dressings with different therapeutic qualities and low-cost.

Several oils and extracts of medicinal plants and dressings of animal origin [20] are currently used in regenerative medicine to stop bleeding, to reduce the effects of contamination on injuries, to modulate the healing process, and to promote better esthetic results with reduced scar formation [21,22]. The andiroba (Carapa guianensis) seed oil is widely used in traditional medicine for its pharmacological properties. It is extracted from the seed and has anti-inflammatory, analgesic, antiallergic, antimicrobial, and healing properties, which are derived from its biologically active constituents such as limonoids and triterpenes [23-25]. Thus, the present study aimed to develop PCL films incorporated with andiroba oil (hybrids) like a scaffold to the wound healing process, using the solvent casting technique. This technique is commonly used to synthesize PCL, and PCL-based films for wound dressings purposes, where porous and bio-resorbable materials have been obtained in an accessible manner [26]. It does not require specific equipment and is suitable for the large-scale production of low cytotoxicity and cost wound dressings [27]. Here, we focus on PCL's hybridization, using andiroba oil as an active compound to create a multifunctional wound dressing. The objective was to assess these materials' thermal, surface, and biological properties, to a more natural and straightforward treatment.

\section{Materials and Methods}

\subsection{Materials}

Poly ( $\varepsilon$-caprolactone) $(\mathrm{PCL})\left(\mathrm{M}_{\mathrm{n}}=45,000\right.$ and $\left.\delta=\left(\left(9.65 \mathrm{cal} \mathrm{cm}^{-3}\right)^{1 / 2}\right)\right)$, dimethyl sulfoxide, phosphate-buffered saline (PBS) and amphotericin B were supplied by SigmaAldrich (Barueri, Brazil). Andiroba oil (AO) was provided by Amazon Oil (Belém, Brazil). Its physic-chemical characteristics are listed in Table 1 . Acetone $\left(\left(\delta^{*}=9.77\left(\mathrm{cal} \mathrm{cm}^{-3}\right)^{1 / 2}\right)\right.$, acetic acid $\left(\left(\delta^{*}=10.5 \mathrm{cal} \mathrm{cm}^{-3}\right)^{1 / 2}\right)$ and dichloromethane $\left(\delta^{*}=9.70\left(\mathrm{cal} \mathrm{cm}^{-3}\right)^{1 / 2}\right)$ were purchased from Neon Comercial (Belém, Brazil). Penicillin-streptomycin was supplied by Nacalai Tesque (Kyoto, Japan). The L929 cell line was obtained from American Type Culture Collection (Rockville, MD, USA). ${ }^{*} \delta$ = solubility parameter [28-30]. 
Table 1. Physicochemical properties of commercial andiroba oil.

\begin{tabular}{ccc}
\hline Physicochemical Data & Units & Values * \\
\hline Acidity level & $\%$ weight & $<15.0$ \\
Density & $25^{\circ} \mathrm{C} \mathrm{g} / \mathrm{mL}$ & 0.9261 \\
Iodine index & $\mathrm{gI}_{2} / 100 \mathrm{~g}$ & $55-80$ \\
Melting point & ${ }^{\circ} \mathrm{C}$ & 22 \\
Peroxide content & $10 \mathrm{meq} \mathrm{O} / \mathrm{kg}$ & $<10.0$ \\
Saponification index & $\mathrm{mg} \mathrm{KOH} / \mathrm{g}$ & $190-210$ \\
Unsaponifiable matter (bioactive) & $\%$ & $3-5$ \\
\hline${ }^{*}$ Data obtained by the Amazon Oil supplier. & &
\end{tabular}

\subsection{Fabrication of PCL Casting Films}

PCL hybrids films were obtained from the solvent casting technique (Figure 1), using different solvents (acetic acid, acetone, and dichloromethane). The polymer solution concentration was kept constant at $5 \% w / v$. Andiroba oil was added to the polymeric solution at room temperature until homogenized, without phase separation. Two concentrations were evaluated to hybrids films, $1.7 \% w / w$ and $2.7 \% w / w$ (g of andiroba oil $/ \mathrm{g}$ of PCL). After 10 min stirring, the mixture (PCL solution/oil) was applied to the cylindrical silicone mold, with a volume constant $(5 \mathrm{~mL})$. The films were dried for one week at room temperature and another four days in a vacuum oven at $40{ }^{\circ} \mathrm{C}$ to remove the solvent's residual traces. PCL without oil was synthesized as a control film under the same conditions. Table 2 summarizes the compositions of each sample.
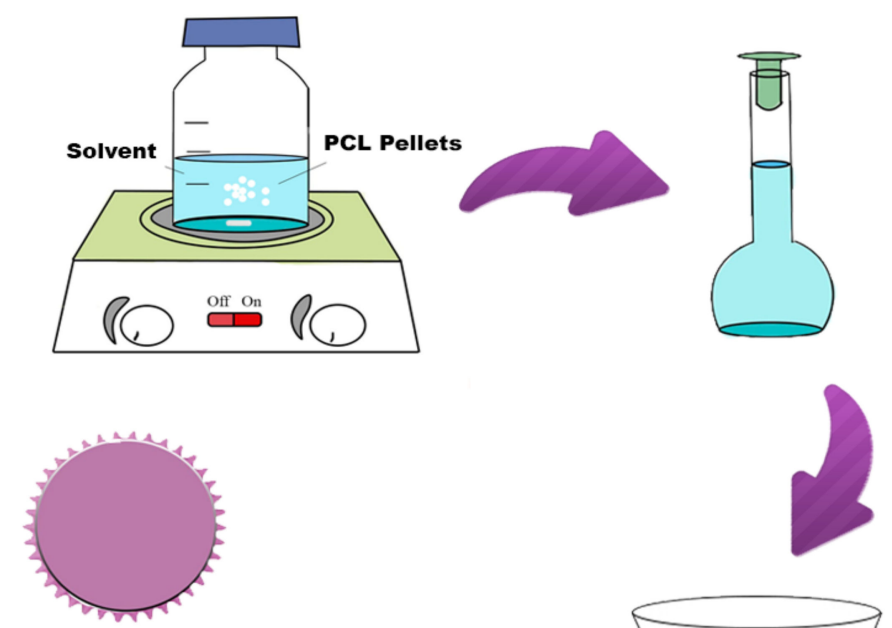

Film

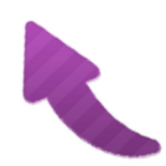

\section{Drying}

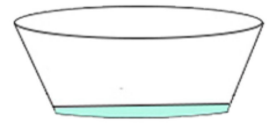

Figure 1. Schematic diagram of poly ( $\varepsilon$-caprolactone) (PCL) film synthesis by the solvent casting technique.

\subsection{Fatty Acid Composition of Andiroba Oil (Carapa guianensis)}

The fatty acid composition of andiroba oil was determined by the American Oil Chemists' Society's official methods [31,32]. It was used a Varian CP 3800 gas chromatograph system (GC) (São Paulo, Brazil), equipped with a capillary column Agilent (30 m $\times$ $0.32 \mathrm{~mm}$ CP WAX $52 \mathrm{CB}$ ) (Santa Clara, CA, USA) and a hydrogen flame ionization detector (Varian, São Paulo, Brazil). The analysis was performed under the following conditions: helium as a carrier gas, adjusted at a flow rate of $1 \mathrm{~mL} \mathrm{~min}^{-1}$; programmed temperature 
to ramp from $50-250{ }^{\circ} \mathrm{C}$ at $10{ }^{\circ} \mathrm{C}$. $\mathrm{min}^{-1}$; detector temperature set to $270{ }^{\circ} \mathrm{C}$; split mode injection for $1 \mu \mathrm{L}$ (1:10); and injector temperature at $250^{\circ} \mathrm{C}$. The quantitative data were performed by peak area normalization. The fatty acid methyl esters were identified by comparing their retention indices with fatty acid methyl ester standards (Table 3). The analyses were performed in triplicate.

Table 2. Samples identification and composition.

\begin{tabular}{|c|c|c|}
\hline Sample Name & Solvent & $\begin{array}{l}\text { Andiroba oil (AO) } \\
\left(\% \mathrm{wt} \text { OIL } / w t_{\mathrm{PCL}}\right)\end{array}$ \\
\hline PAcA-control & Acetic Acid & - \\
\hline PAcA-1.7 & Acetic Acid & 1.7 \\
\hline PAcA-2.7 & Acetic Acid & 2.7 \\
\hline PAC-control & Acetone & - \\
\hline PAC-1.7 & Acetone & 1.7 \\
\hline PAC-2.7 & Acetone & 2.7 \\
\hline PD-control & Dichloromethane & - \\
\hline PD-1.7 & Dichloromethane & 1.7 \\
\hline PD-2.7 & Dichloromethane & 2.7 \\
\hline
\end{tabular}

Table 3. Fatty acids composition of andiroba seed oil (Carapa guianensis) determined by gas chromatography.

\begin{tabular}{|c|c|c|}
\hline Nomenclature & Chain & Composition * $(\%)$ \\
\hline Lauric acid & C12:0 & $0.89 \pm 0.38$ \\
\hline Myristic acid & C14:0 & $0.68 \pm 0.25$ \\
\hline Palmitic acid & $\mathrm{C} 16: 0$ & $26.89 \pm 0.98$ \\
\hline Palmitoleic acid & C16:1 & $0.81 \pm 0.06$ \\
\hline Heptadecanoic acid & $\mathrm{C} 17: 0$ & $0.29 \pm 0.34$ \\
\hline Stearic acid & C18:0 & $8.80 \pm 0.10$ \\
\hline Oleic acid & C18:1 ( $\omega-9)$ & $48.67 \pm 1.19$ \\
\hline Linoleic acid & C18:2 (w-6) & $10.79 \pm 0.39$ \\
\hline Linolenic acid & $\mathrm{C} 18: 3(\omega-3)$ & $0.22 \pm 0.02$ \\
\hline Arachidic acid & C 20:0 & $1.30 \pm 0.16$ \\
\hline Behenic acid & C22:0 & $0.25 \pm 0.14$ \\
\hline Lignoceric acid & C24:0 & $0.20 \pm 0.04$ \\
\hline
\end{tabular}

${ }^{*}$ Average values and standard derivations of the three andiroba oil (AO) samples studied.

\subsection{Thermal Analysis}

A Shimadzu DTG-60H thermogravimetric analyzer (TGA) (Kyoto, Japan) was used to evaluate samples' thermal stability. Approximately 5-8 mg of samples were weighed into an aluminum pan. The experiments were done from 25 to $550{ }^{\circ} \mathrm{C}$ at a heating rate of $10^{\circ} \mathrm{C} . \mathrm{min}^{-1}$, under dynamic nitrogen atmosphere $\left(50 \mathrm{~mL} \mathrm{~min}^{-1}\right)$. The glass transition temperature $\left(T_{g}\right)$ and melting temperature $\left(T_{m}\right)$ were determined using a differential scanning calorimeter, model DSC60 plus (Kyoto, Japan, Shimadzu Corporation). The specimens were scanned from 35 to $250{ }^{\circ} \mathrm{C}$, with isotherms for $5 \mathrm{~min}$, cooling from 250 to $35{ }^{\circ} \mathrm{C}$, isothermal for $5 \mathrm{~min}$, and heated again from 35 to $250{ }^{\circ} \mathrm{C}$. The films' thermal history was eliminated in heating and cooling consecutive programs, and the second run measured the transition temperatures. TGA and DSC thermograms were evaluated by Origin pro 9.1 software (Originlab Corporation, Northampton, MA, USA). Enthalpy of fusion $\left(\Delta H_{m}\right)$ was determined by the area under the endothermic peak (integrating the melting peak below the baseline). The degree of crystallinity $(x c)$ of films was calculated using Equation (1)

$$
x_{c}(\%)=\frac{\Delta H m}{\Delta H m^{\infty} \varphi} \times 100
$$


where $\Delta H m, \Delta H m^{\infty}$, and $\varphi$ are the experimental endothermic enthalpy of fusion $\left(\mathrm{J} \mathrm{g}^{-1}\right)$, the theoretical enthalpy of $100 \%$ crystalline PCL, taken $136.5 \mathrm{~J} \mathrm{~g}^{-1}$ [33] and the weight fraction of the PCL.

\subsection{Fourier-Transform Infrared Spectroscopy (FTIR)}

FTIR absorption spectra were recorded using a Agilent spectrophotometer, model cary 630 (Hanover, Germany), equipped with ATR to evaluate specimens' vibrational mode. IR analysis was carried out in the range from 4000 to $650 \mathrm{~cm}^{-1}$, with a resolution of $8 \mathrm{~cm}^{-1}$ and 32 scans.

\subsection{Surface Characterization}

The surface morphology (porosity and roughness) was investigated using a Jeol JSM6610LV scanning electron microscope (SEM) (Tokyo, Japan). The samples were covered with a thin gold layer (Denton Vacuum, model Desk V, Moorestown, NJ, USA) and evaluated with accelerating voltage $1 \mathrm{kV}$ and magnification $1000 \times$. The hydrophilicity property of polymer film was investigated using angle contact angle measurements. The sessile drop method was used at room temperature. The average angle of deionized water droplets on the material's surface was obtained from six measurements for each sample. Water drop images were recorded using Nikon b500 $16 \mathrm{mp} / 40 \times$ photographic camera and analyzed by Image J. software. The thickness of the pieces was determined using the micrometer.

\subsection{In Vitro Tests}

\subsubsection{D Cell Culture}

Fibroblast lineage cells (L929) (Rockville, MD, USA) were incubated in 96-well plates at a density of $2 \times 10^{4}$ cells/well. The experiment was performed in an incubator at $37^{\circ} \mathrm{C}$, humidified, $5 \% \mathrm{CO}_{2} / 95 \%$ air environment at $24 \mathrm{~h}$. The Dulbecco's modified Eagle's medium (DMEM) with $10 \%$ bovine fetal serum (SBF)(Gibco ${ }^{\mathrm{TM}}$, Sao Paulo, Brazil), contained 100 units $/ \mathrm{mL}$ penicillin, and $50 \mu \mathrm{g} / \mathrm{mL}$ streptomycin was used for cell nutrition and maintenance.

\subsubsection{Cell Viability Assay}

The films were placed at the bottom of the well covering all surfaces, and cell viability was performed using the 3-(4,5-dimethyl-thiazol-2-yl)-2,5-diphenyl-tetrazolium bromide (MTT) assay [34]. The methodology consists of soluble chromogen (MTT) conversion to slightly soluble formazan via dehydrogenases present in viable cells. Then, dimethyl sulfoxide (100 ul) was added to each well to measure the MTT product (formazan). After, the content of formazan crystals was evaluated at $570 \mathrm{~nm}$ by a scanning multi-well spectrophotometer plate reader (ELISA reader, Bio-Rad 2550 EIA, Hercules, CA, USA). The blue color intensity in control (only cells) wells was designated as 100\% viability. The groups evaluated were: (1) control (cell only); (2) PAcA-control; (3) PAcA-1.7, and (4) PAcA-2.7. All further comparisons were based on this reference level to determine the percentage of cell viability. The experiments were performed in quadruplicate, and the results are presented as mean \pm standard deviation.

\subsubsection{Fluid Absorption Capacity/Degree of Swelling}

The phosphate-buffered saline (PBS) and protein milk-based solution, both with $\mathrm{pH}=6.3$, were used for the assessment of biomaterial as a function of macromolecule permeability. The materials were previously cut into pieces of $1 \mathrm{~cm}^{2}$ and weighted. Through the differences in the weight of the materials, the absorption volume was quantified by Equation (2). $W_{s}$ is the swollen sample weight, and $W_{d}$ is the dry sample weight. The immersion was done at $37^{\circ} \mathrm{C}$ (body temperature) for $1 \mathrm{~h}$.

$$
\text { Degree of swelling }(\%)=\frac{W s-W d}{W d} \times 100
$$




\subsubsection{Statistical Analysis}

The significance of the difference between the mean concentration of material absorption and standard control was tested using the Mann-Whitney U procedure for nonparametric data sets. The meaning of cell viability was performed by ANOVA One-Way, with a significance level of $p<0.05$. The GraphPad Prism software (version 6.01, La Jolla, San Diego, CA, USA) was used.

\section{Results and Discussion}

\subsection{Fatty Acid Composition of Andiroba Seed Oil (Carapa guianensis)}

Andiroba oil (AO) has often been studied as an insect repellent [35]. However, their physic-chemical properties can offer new opportunities for use in wound care. Table 3 shows the chemical composition of the fatty acids in the andiroba seed oil, and the profile agrees with that described in the literature [36,37]. In total, twelve methyl esters were identified, and about $60.5 \%$ account for the averaged composition of unsaturated fatty acids. The major compounds found were oleic acid $(48.67 \%)$, palmitic acid $(26.89 \%)$, linoleic acid $(10.79 \%)$, and stearic acid $(8.80 \%)$. In smaller percentage following acids can be seen: lauric $(0.89 \%)$, myristic $(0.68 \%)$, palmitoleic $(0.81 \%)$, arachidic $(1.30 \%)$, behenic $(0.25 \%)$, heptadecanoic $(0.29 \%)$ and lignoceric acid $(0.20 \%)$. These acids play a key role in wound care, with emollient action and biological properties [37,38]. Cutaneous dressings need to act as a bacterial barrier and prevent dehydration of the skin. Linoleic acid integrates the stratum corneum and prevents transepidermal water loss, ensuring its integrity $[39,40]$. This compound favors autolytic debridement in the wound and accelerates the healing process.

Additionally, oleic acid (Omega 9) and linoleic acid (Omega 6) are essentials fatty acids (AGE), which participate in human metabolism and nutrition. AGE induces the tissue granulation process, facilitates cell proliferation, and increases the membrane's cell permeability, protecting the lesion [40]. The presence of non-fatty acid components (tocopherols, carotene, and tetranortriterpenoids) also attributes other medicinal properties and anti-inflammatory effects to the $\mathrm{AO}[37,41-43]$.

\subsection{Surface Characterization}

\subsubsection{Optical and SEM Imaging of PCL Casting Films}

The type of solvent and their evaporation rate are some critical parameters that affect the surface, physic-chemical and biological properties of films on the solvent casting method [44]. Figure 2 shows the optical and microscopic images of PCL control and hybrids film, respectively. Three different solvents were evaluated: acetone, dichloromethane, and acetic acid to determine an optimum solvent system. All polymer solutions formed opaque films. No macroscopic phase separation was observed after casting of samples, which suggests high PCL molecular weight and enough Van der Waals forces to aggregate the solution's polymer chains [45]. Figure 2A shows optical images of samples dissolved in dichloromethane $(\mathrm{DCM})$. The high solvent evaporation rate (boiling point $39.6{ }^{\circ} \mathrm{C}$ ) induced specimens with body deformation, air bubbles, inhomogeneous surfaces, irregular shape, and dimensional shrinkage [44]. The solvent molecules diffusion fast generated smooth and dense surfaces, as can be seen in Figure 2D. Although nonpolar organic solvent facilitates the PCL solubilization process due to higher solvent-polymer chemical affinity, the low difference between its solubility parameters $\left(\left(\delta=0.05\left(\mathrm{cal} \mathrm{cm}^{-3}\right)^{\frac{1}{2}}\right)\right.$ can make difficult the mass transport of volatile and the use of DCM as a porogen [46]. 


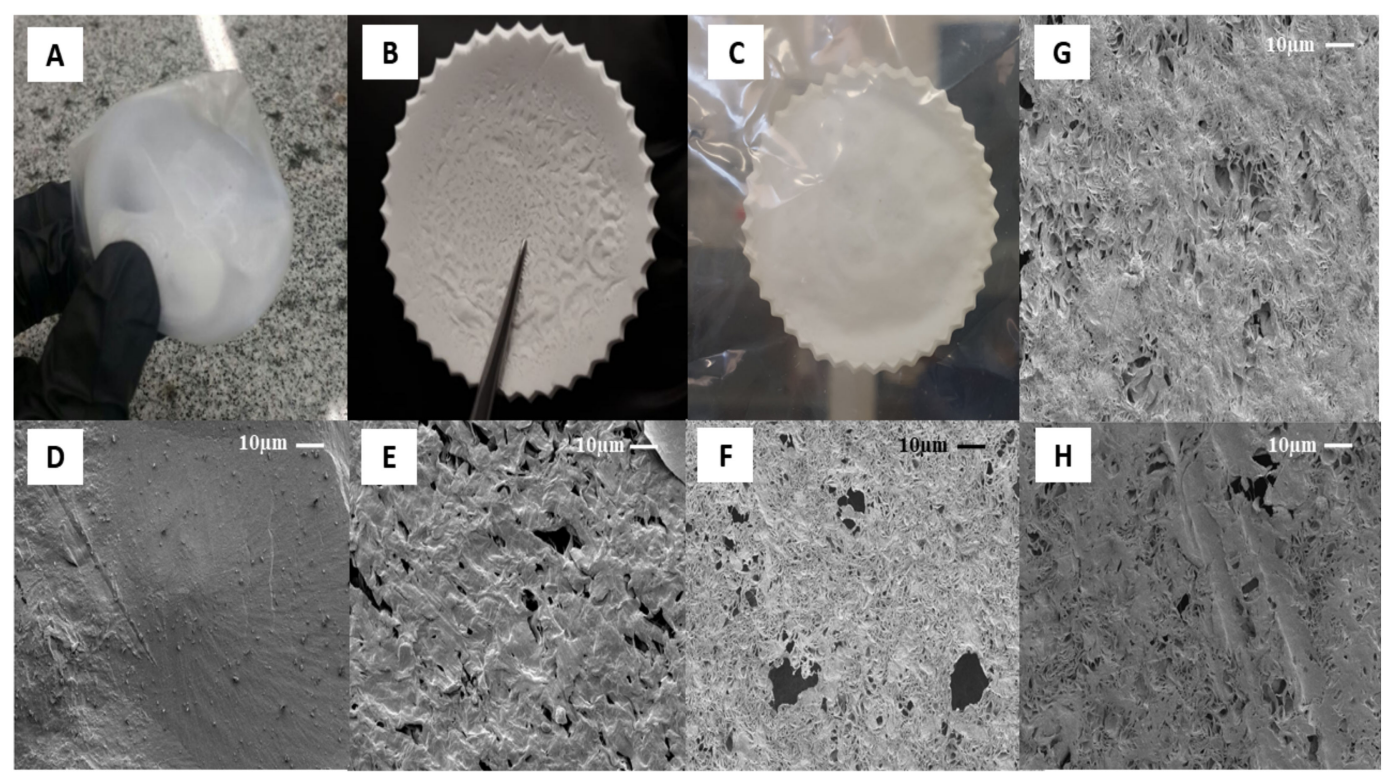

Figure 2. The optical images (OI) and microscopic (SEM) of PCL casting film at magnification $1000 \times$, respectively: (A) PDcontrol OI; (B) PAC-control OI; (C) PAcA-control OI; (D) PD-control SEM; (E) PAC-control SEM; (F) PAcA-control SEM; (G) PAcA-1.7 SEM; (H) PAcA-2.7 SEM.

On the other hand, porous structures were observed on films formed by acetone (boiling point $56.0^{\circ} \mathrm{C}$, Figure $2 \mathrm{E}$ ) and acetic acid (boiling point $118{ }^{\circ} \mathrm{C}$, Figure $2 \mathrm{~F}$ ). Volatile species (solvent) escaped from the film surface and allowed pores' organization to different diameters ( 0.5 to $19.8 \mu \mathrm{m})$. This characteristic plays a role in inducing cell penetration and proliferation, the mass transport of nutrients, and tissue growth [47]. Additionally, acetone vapor trapping under solidified samples was observed (central region, Figure 2B). Factors as room temperature, drying environment, humidity [48] and Amazonian climate affected the solvent's gradual evaporation kinetics (low evaporation rate). Acetic acid was observed to possess excellent film-forming properties. The samples presented a regular surface, uniform thickness, and good mechanical handling strength (Figure 2C). This behavior may have been influenced by viscoelasticity, the degree of entanglement of the chains in solution, and the solvent molecules' size [49]. An acidic solvent can decrease the PCL polymeric chain by breaking of ester linkages, affecting the viscosity of solution and morphology on the surface [50]. Considering its potential to inhibit bacteria colonization, such as Escherichia coli and Staphylococcus aureus [45], the acetic acid was selected as the optimum solvent system to obtain PCL hybrids films (PCL/AO). By adding AO, in the case of samples PAcA-1.7 (Figure 2G) and PAcA-2.7 (Figure 2H), a decrease in the number and size of pores was observed. From the SEM micrograph, AO partially filled the empty spaces on the material surface. The porosity decreases as the concentration of oil increases. Visually, there are no significant differences between the oil-loaded film and the control sample; only an increase in the film's initial thickness was detected ( $>50 \%)$. No migration of oil to the surface was observed, suggesting good interaction to system PCL/AO.

\subsubsection{Water Contact Angle Measurement}

Table 4 displays the water contact angle measurements for control and hybridized polycaprolactone film, and the results were reported as mean values and standard deviation. Andiroba oil content and surface morphology affected the hydrophilic property of samples, decreasing their interaction with water. This behavior can be explained by the nonpolar group content on the film's surface and triglycerides' chemical structure. The contact angle

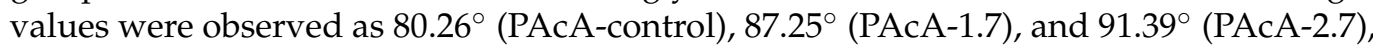
and are according appropriate range for adhesion cell of scaffolds [51,52]. 
Table 4. Water contact angle measurements (average \pm standard deviation) for control and hybrid samples of PCL.

\begin{tabular}{cc}
\hline Samples & Water Contact Angle/Degrees \\
\hline PAcA-control & $80.26 \pm 5.72$ \\
PAcA-1.7 & $87.25 \pm 6.05$ \\
PAcA-2.7 & $91.39 \pm 5.10$ \\
\hline
\end{tabular}

\subsection{Fourier-Transform Infrared Spectroscopy (FTIR) Analysis}

FTIR spectroscopy is a useful technique to investigate the chemical structure of organic molecules and understanding changes in their band position and vibrational modes. Clearly, the IR visual inspection showed great similarities and overlapping of the data in samples' spectral profiles (Figure 3). In the spectrum of andiroba oil, the fingerprint region at $2900-2850 \mathrm{~cm}^{-1}$ is assigned to stretching vibration of $\mathrm{CH}_{2}$ groups; peaks at $1746 \mathrm{~cm}^{-1}$ and $1464 \mathrm{~cm}^{-1}$ are attributed to $-\mathrm{C}=\mathrm{O}$ stretching (saturated aliphatic ester) and $-\mathrm{C}-\mathrm{H}$ bending vibrations, respectively; bands in the range $1200-1160 \mathrm{~cm}^{-1}$ are related to the-C-O stretching $[35,53]$. PCL typical bands were observed for all casting films: in the region $3000-2860 \mathrm{~cm}^{-1}$, which represents the C-H asymmetric and symmetric stretching vibration of aliphatic carbons and peaks at $1720 \mathrm{~cm}^{-1}$, due to the presence of the ester carbonyl group $(\mathrm{C}=\mathrm{O}$ stretching) [54-57]. Some differences in the peak intensity and position also may be observed for hybrid samples (PAcA-1.7 and PAcA-2.7), according to the increasing amount of andiroba oil. Bands at 1160 and $1165 \mathrm{~cm}^{-1}$ are assigned to $-\mathrm{C}-\mathrm{O}$ stretching of andiroba oil [53] and to the -C-O stretching vibration in the amorphous phase of PCL [57].

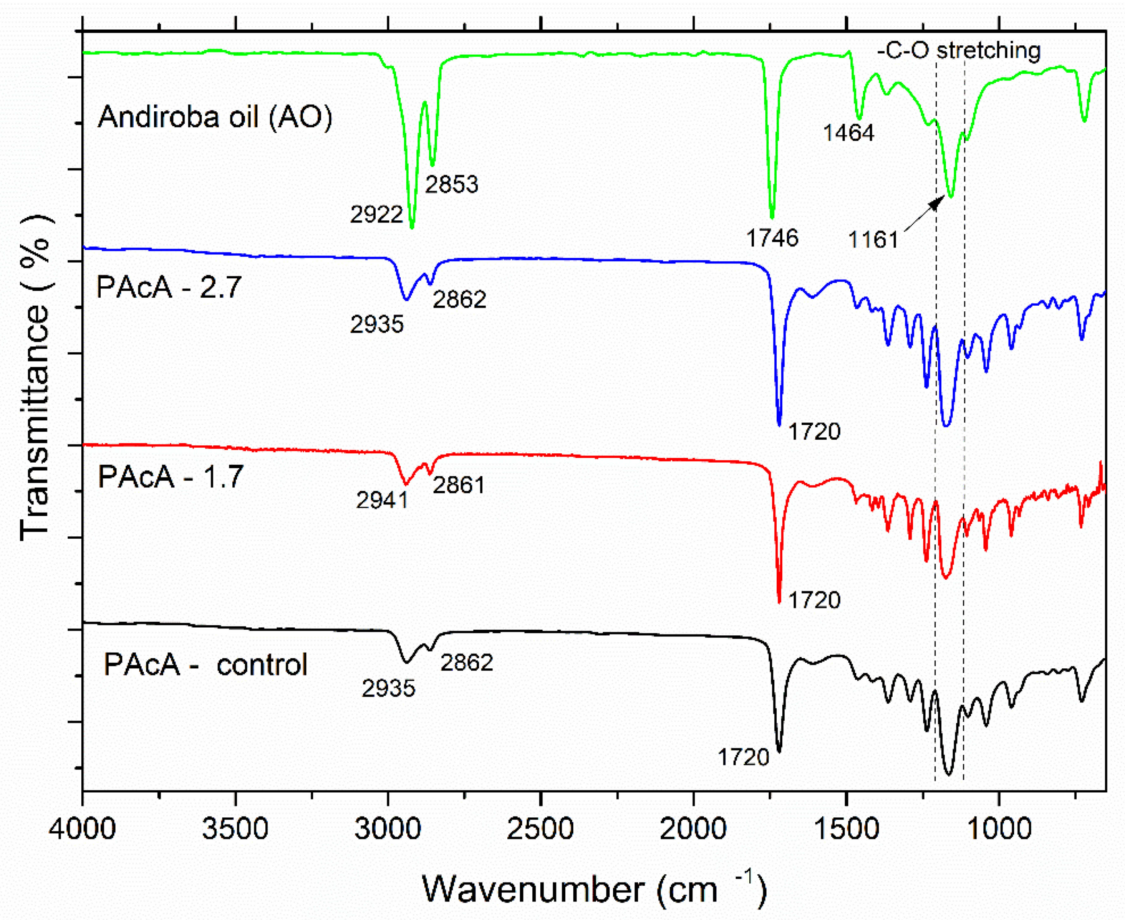

Figure 3. Fourier-transform infrared spectroscopy (FTIR) of andiroba oil and control and hybrids film of PCL.

\subsection{Thermogravimetric Analysis and Its Derivates (TGA and DrTGA)}

Figure 4 displays the TGA curves and their derivates (DrTGA) for PCL control and hybrid film and andiroba oil. The maximum decomposition (Tdmax), onset degradation temperatures (Tonset), mass loss, and the percentage of residues are given in Table 5. The thermal degradation of the PAcA-control sample occurs between $242.7^{\circ} \mathrm{C}$ (Tonset) and $450{ }^{\circ} \mathrm{C}$, in a single mass loss step $(96.5 \%)$ and maximum degradation temperature (Tdmax) 
of $249.8^{\circ} \mathrm{C}$. This event can be attributed to the chemical bond cleavage of polyester chains by the pyrolysis reaction. In Figure $4 \mathrm{a}$, it was observed four stages of weight loss for andiroba oil (AO), which began to degrade at $150{ }^{\circ} \mathrm{C}$ (Tonset) and are entirely decomposed above $531.3^{\circ} \mathrm{C}$ with $99.9 \%$ of weight loss. The first step can be attributed to the evaporation and/or pyrolysis of smaller carbon chain fatty acids (C12-C16:1) at the maximum degradation temperature (Tdmax) of $249.8^{\circ} \mathrm{C}$. Triglycerides with long-carbon chains tend to be thermally decomposed above $288.1{ }^{\circ} \mathrm{C}$ (Tonset) due to the higher boiling point. Around $404{ }^{\circ} \mathrm{C}$ and $482{ }^{\circ} \mathrm{C}$ (Tonset) probably occur the decomposition of stearic, oleic, linoleic, linolenic fatty acids, and others [38]. From Figure 4 b, we also observed that incorporating higher levels of andiroba oil in PCL film tends to shift the Tonset and Tdmax to higher values and reduces the mass residue percentage $(0.5 \%)$. This increase in the degradation temperatures may be related to the barrier effect caused by polymer chains to the $\mathrm{AO}$ molecules, making it difficult to diffusion volatile compounds and increase the thermal stability of hybrid materials.
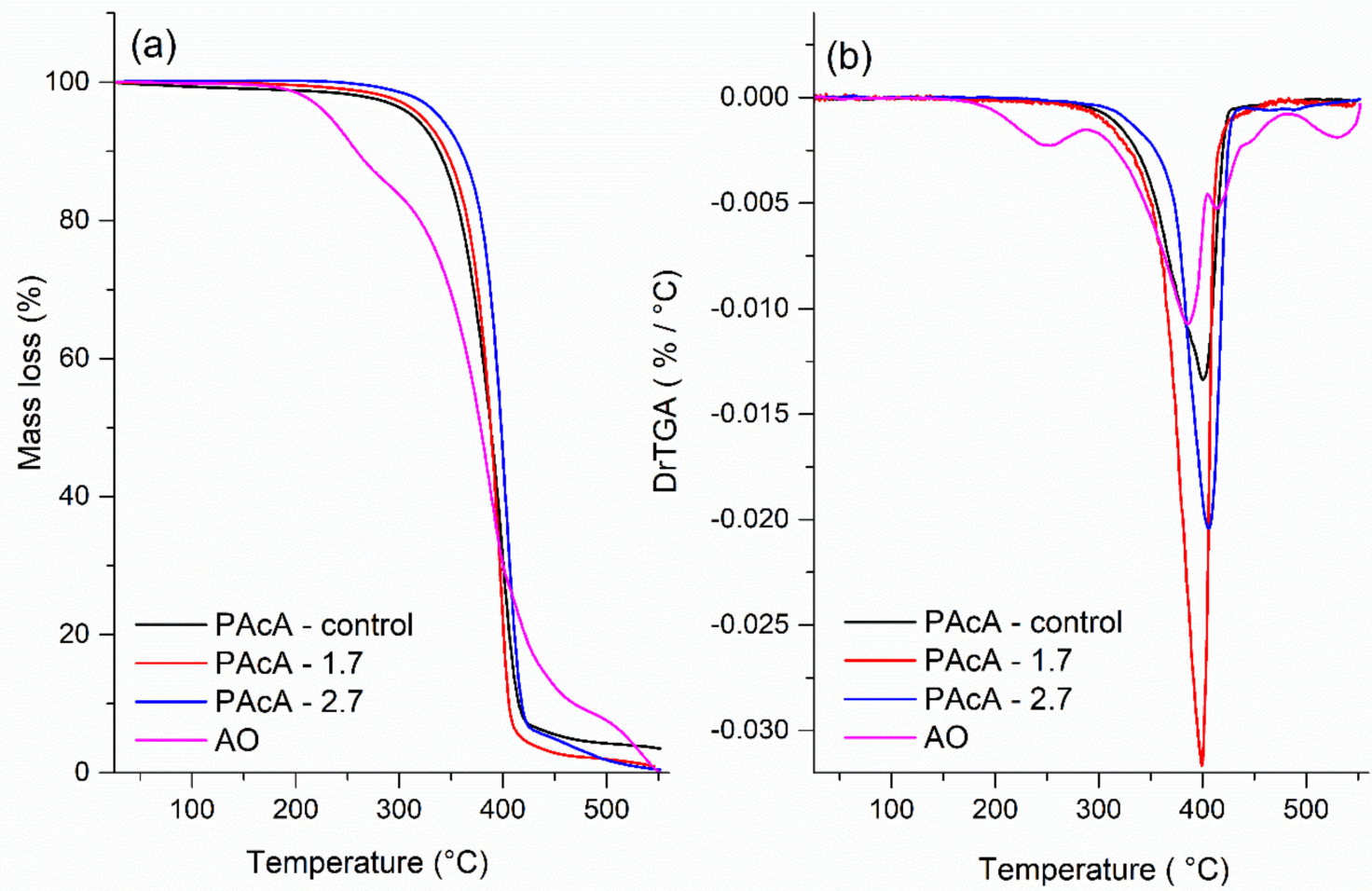

Figure 4. (a) TGA (b) and DrTGA analysis of andiroba oil and PCL films in acetic acid (PAcA-control, PAcA-1.7, PAcA-2.7).

Table 5. TGA and DrTGA curves parameters of the PCL casting films and andiroba oil: degradation onset temperature (Tonset), maximum degradation temperature (Tdmax), weight loss (\%), and the percentage of residues.

\begin{tabular}{|c|c|c|c|c|c|c|c|c|c|c|}
\hline \multirow{2}{*}{ Samples } & \multicolumn{4}{|c|}{ Tonset $\left({ }^{\circ} \mathrm{C}\right)$} & \multicolumn{4}{|c|}{$\operatorname{Tdmax}\left({ }^{\circ} \mathrm{C}\right)$} & \multirow{2}{*}{$\begin{array}{l}\text { Weight } \\
\text { Loss (\%) }\end{array}$} & \multirow{2}{*}{$\begin{array}{c}\text { Residue } \\
\quad(\%)\end{array}$} \\
\hline & $1^{\circ}$ Stage & $2^{\circ}$ Stage & $3^{\circ}$ Stage & $4^{\circ}$ Stage & $1^{\circ}$ Stage & $2^{\circ}$ Stage & $3^{\circ}$ Stage & $4^{\circ}$ Stage & & \\
\hline $\begin{array}{l}\text { PAcA- } \\
\text { control }\end{array}$ & 242.7 & - & - & - & 402.4 & - & - & - & 96.5 & 3.5 \\
\hline PAcA-1.7 & 262.9 & - & - & - & 401.5 & - & - & - & 99.1 & 0.9 \\
\hline PAcA-2.7 & 269.9 & - & - & - & 408.9 & - & - & - & 99.5 & 0.5 \\
\hline $\mathrm{AO}$ & 150.0 & 288.1 & 404.0 & 482.0 & 249.8 & 386.0 & 413.5 & 531.3 & 99.9 & 0.1 \\
\hline
\end{tabular}

\subsection{Differential Scanning Calorimetry (DSC) Nonisothermal Studies}

Figure 5 shows the DSC thermograms for PCL control and hybrid samples. All materials revealed an endothermic peak between 56 and $58{ }^{\circ} \mathrm{C}$, attributed to the polymeric 
matrix melting. The oil incorporation did not show a significant shift on Tm peak. However, more porous media (PAcA-control) can provide higher surface area contact and reduce the flow resistance, improving the heat transfer of scaffolds [58,59].

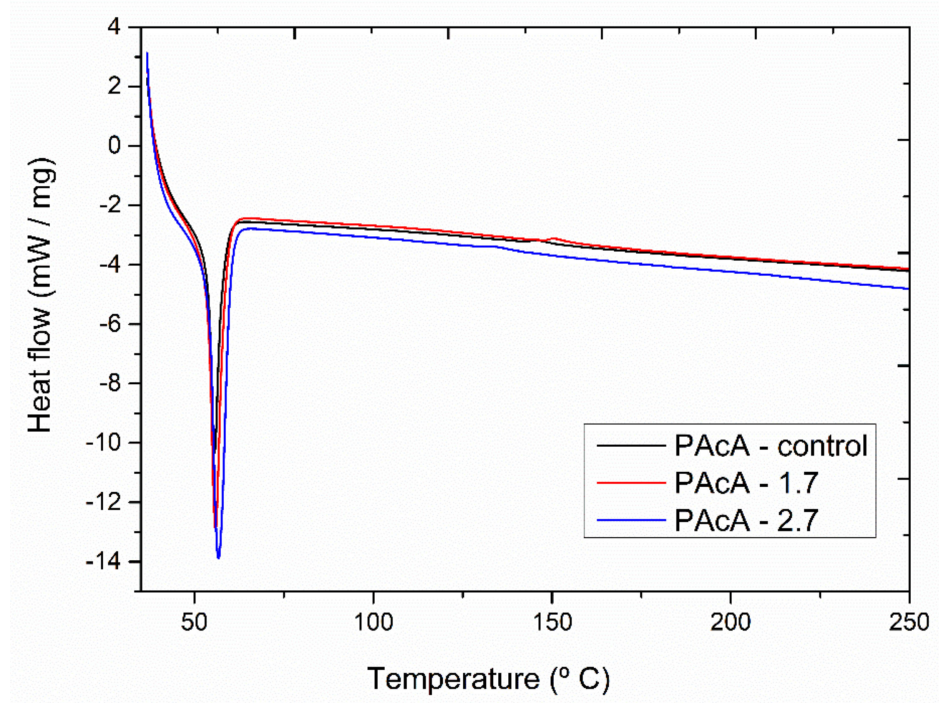

Figure 5. DSC (second heat) analysis of andiroba oil and PCL films in acetic acid (PAcA-control, PAcA-1.7, PAcA-2.7).

The melting enthalpy (areas of endothermic peaks) for the samples PAcA-control, PAcA-1.7, and PAcA-2.7 was $38.93 \mathrm{~J} \mathrm{~g}^{-1}, 46.70 \mathrm{~J} \mathrm{~g}^{-1}$, and $61.31 \mathrm{~J} \mathrm{~g}^{-1}$ (Table 6). An increase in the degree of crystallinity (28.52 to 44.91$)$ and $\Delta H$ was also observed as the oil content increases, decreasing the amorphous domain. The PAcA-2.7 sample showed an increase of $57.46 \%$ to the degree of crystallinity about PAcA-control. The oil dispersion within the PCL chain made it difficult to evaporate the solvent via casting technique, decreasing the evaporation rate of acetic acid. Thus, the polymer chains had more time to reorganize into a more crystalline conformation. Gomes [60] produced more crystalline PCL fibers, reducing the acetic acid content, using 95:5 acetic acid:water ratios. The low volatility and low chemical affinity of acetic acid with the PCL's hydrophobic chain lead to less aggressive solubilization, affecting crystal domains' formation $[61,62]$.

Table 6. DSC curves parameters of the PCL casting films: onset melting temperature (Tm onset), peak melting temperature (Tm peak), enthalpy for melting $(\Delta \mathrm{H})$, and degree of crystallinity (xc\%).

\begin{tabular}{ccccc}
\hline \multicolumn{5}{c}{ Parameters } \\
\hline Samples & Tm Onset $\left({ }^{\circ} \mathbf{C}\right)$ & Tm Peak $\left({ }^{\circ} \mathbf{C}\right)$ & $\Delta \mathbf{H}\left(\mathbf{J ~ g ~ g}^{-\mathbf{1}}\right)$ & xc (\%) \\
\hline PAcA-control & 54.40 & 56.54 & 38.93 & 28.52 \\
PAcA-1.7 & 54.23 & 57.22 & 46.70 & 34.21 \\
PAcA-2.7 & 54.15 & 58.79 & 61.31 & 44.91 \\
\hline
\end{tabular}

\subsection{Cell Viability Assays (MTT)}

As shown in Figure 6, the PAcA-control and hybrids film did not demonstrate cell death $24 \mathrm{~h}$ after cell seed. L929 cells were grown on PAcA-control film, and PAcA-1.7 and PAcA-2.7 samples had a viability of $142.0 \pm 29.85,174.8 \pm 41.72$, and $203.8 \pm 34.33$, respectively. However, there was no statistical difference $(p<0.05)$ between the PAcA-control and hybrids compared to the control group (cell only). In all samples, the proliferation of L929 cells was observed, indicating the high-affinity of the cells for the polymer. Our results are following cytotoxic effects to biodegradable polyester films [63,64]. Both the PAcA-control polymer and the polymer incorporated with the andiroba oil (hybrids sample) do not induce a toxic response on the L929 cell line, demonstrating the ability of PCL casting 
film for cell viability and growth. The insertion of andiroba oil in the PCL matrix also helps in the high cell viability presented. The oil has anti-inflammatory, antimicrobial, and antiallergic potential effects [25], is widely used in traditional medicine to treat joint pain and treat muscle and skin injuries $[65,66]$. The oil still may have antioxidant activities that are important during the inflammatory phase of the healing process [67].

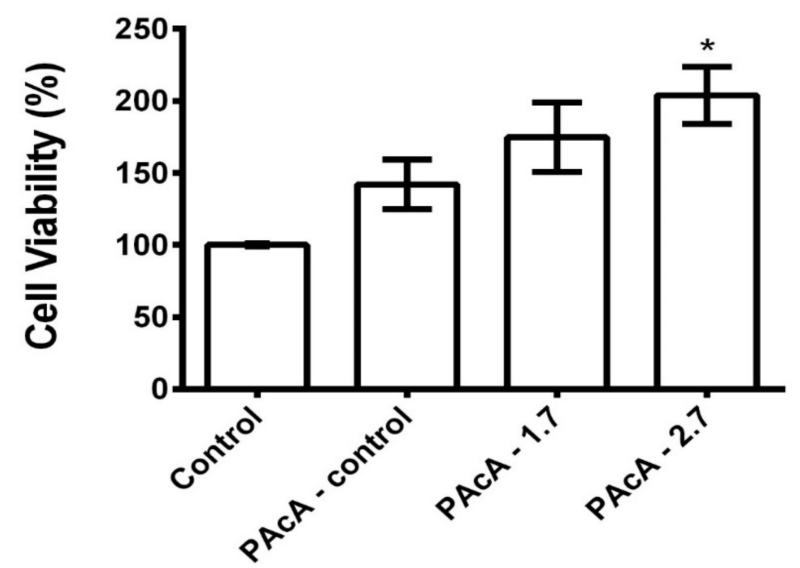

Figure 6. Cell viability of L929 cells on PAcA-control and hybrids (PAcA 1.7 and PAcA-2.7) film after $24 \mathrm{~h}$ in culture. $p<0.05, \mathrm{n}=4$. The asterisk $\left(^{*}\right)$ indicates a significant difference between the control and treated groups.

\subsection{Biological Fluid Absorption Capacity}

Dressings that assist in absorbing exudate, preventing infection, covering the wound, and promoting a moist environment, consequently improve the conditions of the wound bed and assist in its healing [68,69]. We evaluated the material's degree of swelling in different test solutions to use the material as wound dressings, whether exudative or not. Our results suggest a statistically significant difference only between the group with the PAcA-control film, in which greater permeability of protein solution (milk) was observed compared to an aqueous solution (PBS). The swelling may have been influenced by the chemical interactions between solution and hybrid films, molecular diffusion, and surface characteristics. There was no statistically significant difference between the PAcA-1.7 and PAcA-2.7 (Figure 7).

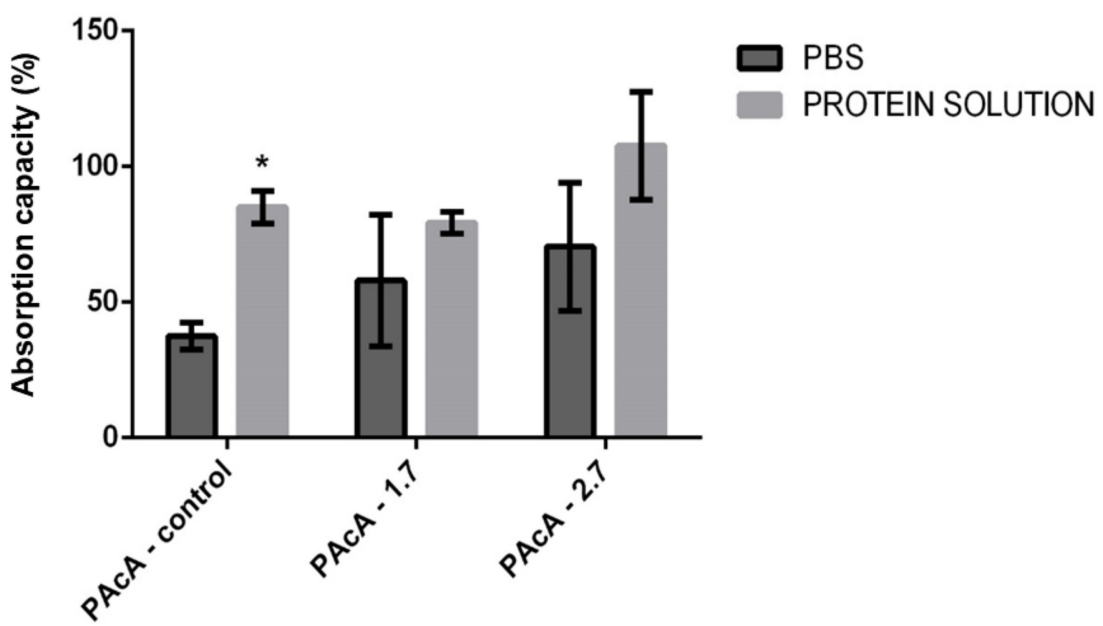

Figure 7. Evaluation of the fluid absorption capacity of PCL control polymeric films (PAcA-control) and incorporated with andiroba oil (PAcA-1.7 and PAcA-2.7) immersed for one hour in aqueous or protein solution. The data were plotted in the average format and standard error of the mean. The analysis was performed by 2-way ANOVA followed by Bonferroni's test, with $p<0.05, \mathrm{n}=4$. The asterisk $\left(^{*}\right)$ indicates a significant difference between the control and treated groups. 


\section{Conclusions}

In this study, PCL-based hybrid films were prepared by solvent casting technique for wound healing applications. Andiroba-oil-loaded PCL membranes were evaluated by surface morphology, water contact angle, functional groups, and thermal behavior. FTIR showed great similarities and overlapping of the data in samples' spectral profiles. Water contact angle measurement and SEM images showed that the AO affects samples' hydrophilicity and porosity, decreasing their interaction with water. DSC analyses showed that andiroba oil affects the evaporation rate of solvent and increases the crystals domains. TGA analysis suggested higher thermal stability of hybrid materials due to the barrier effect caused by polymer chains to the $\mathrm{AO}$ molecules. Viability tests demonstrated the absence of cytotoxicity and proliferation of L929 cells on PCL-AO film. Moreover, the absorption capacity presented by the material probably can make it suitable for biomedical applications, such as wound dressings, which can assist in covering, preventing infection, and, consequently, in the wound healing process. However, mechanical properties assays, antimicrobial and antioxidant activity, and degradation tests in the future should be performed for a successful application of scaffolds in medicine regenerative.

Author Contributions: D.F.S.: Investigation, methodology, validation, writing-original draft preparation. K.T.L.: investigation, validation, methodology, writing-original draft preparation. G.N.T.B.: methodology, data curation, formal analysis, supervision. J.A.R.O.: writing-review and editing, visualization. L.A.S.d.N.: writing - review and editing, visualization, funding acquisition. C.E.F.C.: funding acquisition, resources. G.N.R.F.: funding acquisition, writing-review and editing. V.O.C.C.: formal analysis, methodology. M.F.P.: Conceptualization, investigation, formal analysis, writingreview and editing, supervision, project administration. All authors have read and agreed to the published version of the manuscript.

Funding: This project received funding from The Dean of Research and Graduate Studies (PROPESP / UFPA, Brazil) and the Banco da Amazônia (BASA/UFPA n 2018/212, Brazil).

Institutional Review Board Statement: Not applicable.

Informed Consent Statement: Not applicable.

Conflicts of Interest: The authors declare no conflict of interest. The funders had no role in the design of the study; in the collection, analyses, or interpretation of data; in the writing of the manuscript, or in the decision to publish the results.

\section{References}

1. Wang, X.; Cheng, F.; Liu, J.; Smått, J.-H.; Gepperth, D.; Lastusaari, M.; Xu, C.; Hupa, L. Biocomposites of Copper-Containing Mesoporous Bioactive Glass and Nanofibrillated Cellulose: Biocompatibility and Angiogenic Promotion in Chronic Wound Healing Application. Acta Biomater. 2016, 46, 286-298. [CrossRef]

2. Zhang, H.; Peng, M.; Cheng, T.; Zhao, P.; Qiu, L.; Zhou, J.; Lu, G.; Chen, J. Silver Nanoparticles-Doped Collagen-Alginate Antimicrobial Biocomposite as Potential Wound Dressing. J. Mater. Sci. 2018, 53, 14944-14952. [CrossRef]

3. Kamoun, E.A.; Kenawy, E.-R.S.; Chen, X. A Review on Polymeric Hydrogel Membranes for Wound Dressing Applications: PVA-Based Hydrogel Dressings. J. Adv. Res. 2017, 8, 217-233. [CrossRef]

4. Rogers, V.; George, M.; Luk, A. Silicone Hydrogel Contact Lenses Having Improved Lubricity. U.S. Patent Application n. 16/066,680, 23 May 2019.

5. Panpisut, P.; Toneluck, A. Monomer Conversion, Dimensional Stability, Biaxial Flexural Strength, and Fluoride Release of Resin-Based Restorative Material Containing Alkaline Fillers. Dent. Mater. J. 2020, 39, 608-615. [CrossRef]

6. Tervaert, J.W.C. Silicone. In Mosaic of Autoimmunity; Elsevier: Amsterdam, The Netherlands, 2019; pp. $297-305$.

7. Sadeghianmaryan, A.; Yazdanpanah, Z.; Soltani, Y.A.; Sardroud, H.A.; Nasirtabrizi, M.H.; Chen, X. Curcumin-Loaded Electrospun Polycaprolactone/Montmorillonite Nanocomposite: Wound Dressing Application with Anti-Bacterial and Low Cell Toxicity Properties. J. Biomater. Sci. Polym. Ed. 2020, 31, 169-187. [CrossRef]

8. Parashar, P.; Rathor, M.; Dwivedi, M.; Saraf, S.A. Hyaluronic Acid Decorated Naringenin Nanoparticles: Appraisal of Chemopreventive and Curative Potential for Lung Cancer. Pharmaceutics 2018, 10, 33. [CrossRef] [PubMed]

9. Biswas, S.; Kumari, P.; Lakhani, P.M.; Ghosh, B. Recent Advances in Polymeric Micelles for Anti-Cancer Drug Delivery. Eur. J. Pharm. Sci. 2016, 83, 184-202. [CrossRef] [PubMed]

10. Luo, Y.Y.; Xiong, X.Y.; Tian, Y.; Li, Z.L.; Gong, Y.C.; Li, Y.P. A Review of Biodegradable Polymeric Systems for Oral Insulin Delivery. Drug Deliv. 2016, 23, 1882-1891. [CrossRef] [PubMed] 
11. Li, X.; Zhang, Q.; Ye, D.; Zhang, J.; Guo, Y.; You, R.; Yan, S.; Li, M.; Qu, J. Fabrication and Characterization of Electrospun PCL/Antheraea Pernyi Silk Fibroin Nanofibrous Scaffolds. Polym. Eng. Sci. 2017, 57, 206-213. [CrossRef]

12. Song, R.; Murphy, M.; Li, C.; Ting, K.; Soo, C.; Zheng, Z. Current Development of Biodegradable Polymeric Materials for Biomedical Applications. Drug Des. Devel. Ther. 2018, 12, 3117. [CrossRef] [PubMed]

13. Iaquinta, M.R.; Mazzoni, E.; Manfrini, M.; D’Agostino, A.; Trevisiol, L.; Nocini, R.; Trombelli, L.; Barbanti-Brodano, G.; Martini, F.; Tognon, M. Innovative Biomaterials for Bone Regrowth. Int. J. Mol. Sci. 2019, 20, 618. [CrossRef]

14. Abdal-hay, A.; Raveendran, N.T.; Fournier, B.; Ivanovski, S. Fabrication of Biocompatible and Bioabsorbable Polycaprolactone/Magnesium Hydroxide 3D Printed Scaffolds: Degradation and in Vitro Osteoblasts Interactions. Compos. Part B Eng. 2020, 197, 108158. [CrossRef]

15. Muwaffak, Z.; Goyanes, A.; Clark, V.; Basit, A.W.; Hilton, S.T.; Gaisford, S. Patient-Specific 3D Scanned and 3D Printed Antimicrobial Polycaprolactone Wound Dressings. Int. J. Pharm. 2017, 527, 161-170. [CrossRef]

16. Hajilou, H.; Farahpour, M.R.; Hamishehkar, H. Polycaprolactone Nanofiber Coated with Chitosan and Gamma Oryzanol Functionalized as a Novel Wound Dressing for Healing Infected Wounds. Int. J. Biol. Macromol. 2020, 164, 2358-2369. [CrossRef]

17. Ghitman, J.; Stan, R.; Cecoltan, S.; Chifiriuc, M.C.; Iovu, H. Hybrid Nanocarriers Based on PLGA-Vegetable Oil: A Novel Approach for High Lipophilic Drug Delivery. J. Drug Deliv. Sci. Technol. 2018, 46, 162-172. [CrossRef]

18. Cardoso, P.B.; Araújo, P.H.H.; Sayer, C. Encapsulation of Jojoba and Andiroba Oils by Miniemulsion Polymerization. Effect on Molar Mass Distribution. In:Macromolecular Symposia; WILEY-VCH Verlag: Weinheim, Germany, 2013; Volume 324, pp. 114-123.

19. Uscátegui, Y.L.; Díaz, L.E.; Gómez-Tejedor, J.A.; Vallés-Lluch, A.; Vilariño-Feltrer, G.; Serrano, M.A.; Valero, M.F. Candidate Polyurethanes Based on Castor Oil (Ricinus Communis), with Polycaprolactone Diol and Chitosan Additions, for Use in Biomedical Applications. Molecules 2019, 24, 237. [CrossRef]

20. McIntyre, M.K.; Peacock, T.J.; Akers, K.S.; Burmeister, D.M. Initial Characterization of the Pig Skin Bacteriome and Its Effect on in Vitro Models of Wound Healing. PLoS ONE 2016, 11, e0166176. [CrossRef] [PubMed]

21. Lima Júnior, E.M.; De Moraes Filho, M.O.; Costa, B.A.; Rohleder, A.V.P.; Sales Rocha, M.B.; Fechine, F.V.; Forte, A.J.; Alves, A.P.N.N.; Silva Júnior, F.R.; Martins, C.B. Innovative Burn Treatment Using Tilapia Skin as a Xenograft: A Phase II Randomized Controlled Trial. J. Burn Care Res. 2020, 41, 585-592. [CrossRef]

22. Piriz, M.A.; Lima, C.A.B.; Jardim, V.M.R.; Mesquita, M.K.; Souza, A.D.Z.; Heck, R.M. Medicinal Plants in the Wound Healing Process: A Literature Review. Rev. Bras. Plantas Med. 2014, 16, 628-636. [CrossRef]

23. Krist, S. Andiroba Oil BT-Vegetable Fats and Oils; Krist, S., Ed.; Springer International Publishing: Cham, Switzerland, 2020; pp. 57-60. ISBN 978-3-030-30314-3.

24. Milhomem-Paixão, S.S.R.; Fascineli, M.L.; Roll, M.M.; Longo, J.P.F.; Azevedo, R.B.; Pieczarka, J.C.; Salgado, H.L.C.; Santos, A.S.; Grisolia, C.K. The Lipidome, Genotoxicity, Hematotoxicity and Antioxidant Properties of Andiroba Oil from the Brazilian Amazon. Genet. Mol. Biol. 2016, 39, 248-256. [CrossRef] [PubMed]

25. Wanzeler, A.M.V.; Júnior, S.M.A.; Gomes, J.T.; Gouveia, E.H.H.; Henriques, H.Y.B.; Chaves, R.H.; Soares, B.M.; Salgado, H.L.C.; Santos, A.S.; Tuji, F.M. Therapeutic Effect of Andiroba Oil (Carapa Guianensis Aubl.) against Oral Mucositis: An Experimental Study in Golden Syrian Hamsters. Clin. Oral Investig. 2018, 22, 2069-2079. [CrossRef]

26. Malikmammadov, E.; Tanir, T.E.; Kiziltay, A.; Hasirci, V.; Hasirci, N. PCL and PCL-Based Materials in Biomedical Applications. J. Biomater. Sci. Polym. Ed. 2018, 29, 863-893. [CrossRef] [PubMed]

27. Aliah, N.N.; Ansari, M.N.M. Thermal Analysis on Characterization of Polycaprolactone (PCL)-Chitosan Scaffold for Tissue Engineering. Int. J. Sci. Res. Eng. Technol 2017, 6, 2278-2882.

28. Gorrasi, G.; Guadagno, L.; Vittoria, V. Solvent Induced Polymorphism of Quenched Syndiotactic Polypropylene in Different Liquids. Colloid Polym. Sci. 2003, 281, 469-475. [CrossRef]

29. Bordes, C.; Fréville, V.; Ruffinb, E.; Marotea, P.; Gauvrita, J.Y.; Briançon, S.; Lantéria, P. Determination of Poly(_-Caprolactone) Solubility Parameters: Application to Solvent Substitution in a Microencapsulation Process. Int. J. Pharm. 2010, 383, $236-243$. [CrossRef]

30. Canevarolo, S.V., Jr. Ciência Dos Polímeros.Um Texto Básico Para Tecnólogos e Engenheiros; Artliber Editora: São Paulo, Brazil, 2002.

31. Warner, K.; Eskin, M. Methods to Access Quality and Stability of Oils and Fat-Containing Foods; AOCS Publishing: Urbana, IL, USA, 1995; ISBN 143983198X.

32. American Oil Chemists' Society (AOCS). Official Methods and Recommended Practices of the AOCS, 4th ed.; AOCS: Urbana, IL, USA, 1995.

33. Delgado-Lima, A.; Botelho, G.; Silva, M.M.; Machado, A. V Durability of PCL Nanocomposites under Different Environments. J. Polym. Environ. 2013, 21, 710-717. [CrossRef]

34. Mosmann, T. Rapid Colorimetric Assay for Cellular Growth and Survival: Application to Proliferation and Cytotoxicity Assays. J. Immunol. Methods 1983, 65, 55-63. [CrossRef]

35. Senhorini, G.A.; Zawadzki, S.F.; Farago, P.V.; Zanin, S.M.W.; Marques, F.A. Microparticles of Poly(Hydroxybutyrate-CoHydroxyvalerate) Loaded with Andiroba Oil: Preparation and Characterization. Mater. Sci. Eng. C 2012, 32, $1121-1126$. [CrossRef]

36. Dhorm Pimentel de Moraes, A.R.; Tavares, G.D.; Soares Rocha, F.J.; de Paula, E.; Giorgio, S. Effects of Nanoemulsions Prepared with Essential Oils of Copaiba- and Andiroba against Leishmania Infantum and Leishmania Amazonensis Infections. Exp. Parasitol. 2018, 187, 12-21. [CrossRef] [PubMed] 
37. Novello, Z.; Scapinello, J.; Magro, J.D.; Zin, G.; Di Luccio, M.; Tres, M.V.; Oliveira, J.V. Extraction, Chemical Characterization and Antioxidant Activity of Andiroba Seeds Oil Obtained from Pressurized n-Butane. Ind. Crops Prod. 2015, 76, 697-701. [CrossRef]

38. Dos Santos Costa, M.N.F.; Muniz, M.A.P.; Negrão, C.A.B.; da Costa, C.E.F.; Lamarão, M.L.N.; Morais, L.; Silva Júnior, J.O.C.; Ribeiro Costa, R.M. Characterization of Pentaclethra Macroloba Oil. J. Therm. Anal. Calorim. 2014, 115, 2269-2275. [CrossRef]

39. Manhez, A.C.; Bachion, M.M.; Pereira, Â.L. The Use of Essential Fatty Acids in the Treatments of Wound. Rev. Bras. Enferm. 2008, 61, 620-629.

40. Ferreira, A.M.; de Souza, B.M.V.; Rigotti, M.A.; Loureiro, M.R.D. The Use of Fatty Acids in Wound Care: An Integrative Review of the Brazilian Literature. Rev. Esc. Enferm. USP 2012, 46, 752-760. [CrossRef] [PubMed]

41. Kimura, V.T.; Miyasato, C.S.; Genesi, B.P.; Lopes, P.S.; Yoshida, C.M.P.; Silva, C.F.d. The Effect of Andiroba Oil and Chitosan Concentration on the Physical Properties of Chitosan Emulsion Film. Polimeros 2016, 26, 168-175. [CrossRef]

42. Tappin, M.R.R.; Nakamura, M.J.; Siani, A.C.; Lucchetti, L. Development of an HPLC Method for the Determination of Tetranortriterpenoids in Carapa Guianensis Seed Oil by Experimental Design. J. Pharm. Biomed. Anal. 2008, 48, 1090-1095. [CrossRef] [PubMed]

43. Pardauil, J.J.R.; de Molfetta, F.A.; Braga, M.; de Souza, L.K.C.; Filho, G.N.R.; Zamian, J.R.; da Costa, C.E.F. Characterization, Thermal Properties and Phase Transitions of Amazonian Vegetable Oils. J. Therm. Anal. Calorim. 2017, 127, 1221-1229. [CrossRef]

44. Taherkhani, S.; Moztarzadeh, F. Fabrication of a Poly(E-Caprolactone)/Starch Nanocomposite Scaffold with a SolventCasting/Salt-Leaching Technique for Bone Tissue Engineering Applications. J. Appl. Polym. Sci. 2016, 133. [CrossRef]

45. Chee, T.Y.; Yusoff, A.R.M.; Malek, N.A.N.N. Characterization of Poly(Vinyl Alcohol)-Polycaprolactone Hybridized Scaffold for Potential Skin Tissue Regeneration. Malaysian J. Fundam. Appl. Sci. 2020, 16, 6-9. [CrossRef]

46. Safaei, F.; Khalili, S.; Khorasani, S.N.; Ghasemi-Mobarakeh, L.; Neisiany, R.E. Porogen Effect of Solvents on Pore Size Distribution of Solvent-Casted Polycaprolactone Thin Films. J. Polym. Sci. Eng. 2018, 1. [CrossRef]

47. Thi Hiep, N.; Chan Khon, H.; Dai Hai, N.; Byong-Taek, L.; Van Toi, V.; Thanh Hung, L. Biocompatibility of PCL/PLGA-BCP Porous Scaffold for Bone Tissue Engineering Applications. J. Biomater. Sci. Polym. Ed. 2017, 28, 864-878. [CrossRef]

48. Lucero, J.M.; Jasinski, J.B.; Song, M.; Li, D.; Liu, L.; Liu, J.; De Yoreo, J.J.; Thallapally, P.K.; Carreon, M.A. Synthesis of Porous Organic Cage CC3 via Solvent Modulated Evaporation. Inorg. Chem. Acta 2020. [CrossRef]

49. Costa, R.G.F.; de Oliveira, J.E.; de Paula, G.F.; de S. Picciani, P.H.; de Medeiros, E.S.; Ribeiro, C.; Mattoso, L.H.C. Electrospinning of Polymers in Solution. Part I: Theoretical Foundation. Polímeros 2012, 22, 170-177. [CrossRef]

50. Das, P.; Remigy, J.-C.; Lahitte, J.-F.; van der Meer, A.D.; Garmy-Susini, B.; Coetsier, C.; Desclaux, S.; Bacchin, P. Development of Double Porous Poly ( $\varepsilon$-Caprolactone)/Chitosan Polymer as Tissue Engineering Scaffold. Mater. Sci. Eng. C 2020, $107,110257$. [CrossRef] [PubMed]

51. Rahmati Nejad, M.; Yousefzadeh, M.; Solouk, A. Electrospun PET/PCL Small Diameter Nanofibrous Conduit for Biomedical Application. Mater. Sci. Eng. C 2020, 110, 110692. [CrossRef]

52. Arima, Y.; Iwata, H. Effects of Surface Functional Groups on Protein Adsorption and Subsequent Cell Adhesion Using SelfAssembled Monolayers. J. Mater. Chem. 2007, 17, 4079-4087. [CrossRef]

53. De Santana, F.B.; Mazivila, S.J.; Gontijo, L.C.; Neto, W.B.; Poppi, R.J. Rapid Discrimination Between Authentic and Adulterated Andiroba Oil Using FTIR-HATR Spectroscopy and Random Forest. Food Anal. Methods 2018, 11, 1927-1935. [CrossRef]

54. Herrera-Kao, W.A.; Loría-Bastarrachea, M.I.; Pérez-Padilla, Y.; Cauich-Rodríguez, J.V.; Vázquez-Torres, H.; Cervantes-Uc, J.M. Thermal Degradation of Poly(Caprolactone), Poly(Lactic Acid), and Poly(Hydroxybutyrate) Studied by TGA/FTIR and Other Analytical Techniques. Polym. Bull. 2018, 75, 4191-4205. [CrossRef]

55. Obasi, H.C.; Chaudhry, A.A.; Ijaz, K.; Akhtar, H.; Malik, M.H. Development of Biocomposites from Coir Fibre and Poly (Caprolactone) by Solvent Casting Technique. Polym. Bull. 2018, 75, 1775-1787. [CrossRef]

56. Augustine, R.; Kalarikkal, N.; Thomas, S. Effect of Zinc Oxide Nanoparticles on the in Vitro Degradation of Electrospun Polycaprolactone Membranes in Simulated Body Fluid. Int. J. Polym. Mater. Polym. Biomater. 2016, 65, 28-37. [CrossRef]

57. Abdelrazek, E.M.; Hezma, A.M.; El-khodary, A.; Elzayat, A.M. Spectroscopic Studies and Thermal Properties of PCL/PMMA Biopolymer Blend. Egypt. J. Basic Appl. Sci. 2016, 3, 10-15. [CrossRef]

58. Liang, M.; Fu, C.; Xiao, B.; Luo, L.; Wang, Z. A Fractal Study for the Effective Electrolyte Diffusion through Charged Porous Media. Int. J. Heat Mass Transf. 2019, 137, 365-371. [CrossRef]

59. Kasaeian, A.; Daneshazarian, R.; Mahian, O.; Kolsi, L.; Chamkha, A.J.; Wongwises, S.; Pop, I. Nanofluid Flow and Heat Transfer in Porous Media: A Review of the Latest Developments. Int. J. Heat Mass Transf. 2017, 107, 778-791. [CrossRef]

60. Gomes, S.; Querido, D.; Ferreira, J.L.; Borges, J.P.; Henriques, C.; Silva, J.C. Using Water to Control Electrospun Polycaprolactone Fibre Morphology for Soft Tissue Engineering. J. Polym. Res. 2019, 26, 222. [CrossRef]

61. Del Ángel-Sánchez, K.; Borbolla-Torres, C.I.; Palacios-Pineda, L.M.; Ulloa-Castillo, N.A.; Elías-Zúñiga, A. Development, Fabrication, and Characterization of Composite Polycaprolactone Membranes Reinforced with TiO2 Nanoparticles. Polymers 2019, 11, 1955. [CrossRef] [PubMed]

62. Boucher, D.S. Solubility Parameters and Solvent Affinities for Polycaprolactone: A Comparison of Methods. J. Appl. Polym. Sci. 2020, 137, 48908. [CrossRef]

63. Boyandin, A.; Dvoinina, L.; Sukovatiy, A.; Sukhanova, A. Production of Porous Films Based on Biodegradable Polyesters by the Casting Solution Technique Using a Co-Soluble Porogen (Camphor). Polymers 2020, 12, 1950. [CrossRef] [PubMed] 
64. Patrício, T.; Domingos, M.; Gloria, A.; Bártolo, P. Characterisation of PCL and PCL/PLA Scaffolds for Tissue Engineering. Procedia CIRP 2013, 5, 110-114. [CrossRef]

65. Das Graças Henriques, M.; Penido, C. The Therapeutic Properties of Carapa Guianensis. Curr. Pharm. Des. 2014, 20, 850-856. [CrossRef] [PubMed]

66. Costa-Silva, J.H.; Lima, C.R.; Silva, E.J.R.; Araújo, A.V.; Fraga, M.; E Ribeiro, A.R.; Arruda, A.C.; Lafayette, S.S.L.; Wanderley, A.G. Acute and Subacute Toxicity of the Carapa Guianensis Aublet (Meliaceae) Seed Oil. J. Ethnopharmacol. 2008, 116, 495-500. [CrossRef]

67. Araujo-Lima, C.F.; Fernandes, A.S.; Gomes, E.M.; Oliveira, L.L.; Macedo, A.F.; Antoniassi, R.; Wilhelm, A.E.; Aiub, C.A.F.; Felzenszwalb, I. Antioxidant Activity and Genotoxic Assessment of Crabwood (Andiroba, Carapa Guianensis Aublet) Seed Oils. Oxid. Med. Cell. Longev. 2018. [CrossRef]

68. Wasiak, J.; Cleland, H.; Campbell, F.; Spinks, A. Dressings for Superficial and Partial Thickness Burns. Cochrane Database Syst. Rev. 2013, CD002106. [CrossRef] [PubMed]

69. De Smaniotto, P.H.; Ferreira, M.C.; Isaac, C.; Galli, R. Systematization of Dressings for Clinical Treatment of Wounds. Rev. Bras. Cir. Plástica 2012, 27, 623-626. 